VISION AND TEXTUALITY 
Also by Stephen Melville

PHILOSOPHY BESIDE ITSELF: On Deconstruction and Modernism

Also by Bill Readings

INTRODUCING LYOTARD: Art and Politics

POSTMODERNISM ACROSS THE AGES: Essays for a Postmodernity that

Wasn't Born Yesterday (co-editor with Bennet Schaber) 


\section{VISION AND TEXTUALITY}

Edited by

Stephen Melville

and

Bill Readings 
Selection and editorial matter @ Stephen Melville and the Estate of Bill Readings 1995

Individual chapters (in order) $\odot$ Griselda Pollock,

Michael Ann Holly, John Tagg, Irit Rogoff, Mieke Bal, Norman

Bryson, the estate of Louis Marin, Hal Foster, Françoise Lucbert, John Bender, Peter de Bolla, Thomas Crow, Bennet Schaber,

Rosalind Krauss, Martin Jay, Victor Burgin 1995

All rights reserved. No reproduction, copy or transmission of this publication may be made without written permission.

No paragraph of this publication may be reproduced, copied or transmitted save with written permission or in accordance with the provisions of the Copyright, Designs and Patents Act 1988, or under the terms of any licence permitting limited copying issued by the Copyright Licensing Agency, 90 Tottenham Court Road, London W1P 9HE.

Any person who does any unauthorised act in relation to this publication may be liable to criminal prosecution and civil claims for damages.

First published 1995 by

MACMILLAN PRESS LTD

Houndmills, Basingstoke, Hampshire RG21 2XS

and London

Companies and representatives

throughout the world

ISBN 978-0-333-60970-5

DOI 10.1007/978-1-349-24065-4

A catalogue record for this book is available from the British Library.

Typeset by EXPO Holdings, Malaysia

$\begin{array}{rrrrrrrrrr}10 & 9 & 8 & 7 & 6 & 5 & 4 & 3 & 2 & 1\end{array}$

$\begin{array}{llllllllll}04 & 03 & 02 & 01 & 00 & 99 & 98 & 97 & 96 & 95\end{array}$ 
In memory of Louis Marin 


\section{Contents}

List of Illustrations $\quad$ ix

Acknowledgements xiii

Notes on Contributors xvi

\section{Part I}

1 General Introduction 3

Stephen Melville and Bill Readings

\section{Part II}

2 Basic Concepts. Of Art History Stephen Melville

3 Beholding Art History: Vision, Place and Power Griselda Pollock

4 Past Looking Michael Ann Holly

5 A Discourse (With Shape of Reason Missing) John Tagg

6 The Aesthetics of Post-History: A German Perspective Irit Rogoff

\section{Part III}

7 How Obvious is Art? Kitsch and the Semiotician Bill Readings

8 Reading the Gaze: The Construction of Gender in 'Rembrandt'

Mieke Bal

9 Philostratus and the Imaginary Museum Norman Bryson

10 Topic and Figures of Enunciation: It is Myself that I Paint Louis Marin 
11 Armour Fou

Hal Foster

\section{Part IV}

12 The Pen and the Eye: The Politics of the Gazing Body

Françoise Lucbert

13 Impersonal Violence: The Penetrating Gaze and the Field of Narration in Caleb Williams John Bender

14 The Visibility of Visuality: Vauxhall Gardens and the Siting of the Viewer Peter de Bolla

$15 \mathrm{~B} / \mathrm{G}$

Thomas Crow

\section{Part V}

16 Vision Procured

Bennet Schaber

17 In the Master's Bedroom

Rosalind Krauss

18 Photo-unrealism: The Contribution of the Camera to the Crisis of Ocularcentrism

Martin Jay

19 Chance Encounters: Flâneur and Detraquée in Breton's Nadja Victor Burgin

Index 


\section{List of Illustrations}

1 Poster for Vision and Textuality Conference, 1989

2 Kirk Douglas as Vincent Van Gogh in Lust for Life, MGM Minnelli 1956; Publicity Still, British Film Institute

3 Vincent Van Gogh, Peasant Woman Stooping Seen from Behind and from the Side, 1985; Rijksmuseum Kroeller-Mueller

4 Gustave Caillebotte, Man Looking out of a Window, 1876; Private Collection

5 Mary Cassatt, Woman in Black, 1880; Museum of Fine Arts, Boston

6 Barbara Kruger, Your Gaze Hits the Side of My Face, 1981

7 Edgar Degas, Young Woman with Binoculars, c. 1866; British Museum, London

8 Anonymous, Morisot's Studio, c. 1890;

Collection Sirot-Angel, Paris

9 Mary Kelly, On the Insistence of the Letter, detail: Post-Partum Document, 1979; Arts Council of Great Britain, London

10 Mary Kelly, Corpus: Appel, detail: Interim, 1990;

Collection of the Artist

11 Giorgione da Castelfranco, Sleeping Venus, 1506-8; Gemäldegalerie, Dresden

12 Raphael, School of Athens, c. 1509; Vatican, Rome 71

13 Diego Velasquez, Las Meninas, 1656; Museo del Prado, Madrid

14 Édouard Manet, Olympia, 1863; Musée d'Orsay, Paris

15 Jean-Baptiste Siméon Chardin, The Young

Schoolmistress, 1740; National Gallery, London $\quad 74$

16 Gustave Courbet, The Corn Sifters, 1854;

Musée des Beaux Arts, Nantes

17 Piero della Francesca, The Flagellation of Christ, c. 1450;

Galleria Nazionale delle Marche, Palazzo Ducale, Urbino $\quad 77$

18 Raphael, Marriage of the Virgin, 1504;

Brera Gallery, Milan

19 Peter Blake, The Meeting, or Have a Nice Day, Mr. Hockney, 1981-3. Tate Gallery, London 
20 Gustave Courbet, The Meeting, or Bonjour,

Monsieur Courbet, 1854; Musée Fabre, Montpellier

21 René Magritte, The False Mirror, 1928; Collection,

The Museum of Modern Art, New York

22 Titian, Venus of Urbino, c. 1538;

Uffizi Gallery, Florence

23-25 John Baldessari, Two Crowds

(With Shape of Reason Missing), 1984

26 Pages 64-5 of Jacques Derrida, 'Parergon', in The Truth in Painting, showing a plate of Antonio Fantuzzi,

Ornamental Panel with Empty Oval, 1542-3

27-28 Discourse (With Shape of Reason Missing)

29 Installing the 25th Anniversary Exhibition at the National Gallery of Art, Washington, DC, 1966

30 Installation view of Kazimir Malevich 1878-1935;

National Gallery of Art, Washington, DC, 1990

31 Installation view of The Treasure Houses of Britain:

Five Hundred Years of Private Patronage and Art Collecting;

The Waterloo Gallery, National Gallery of Art,

Washington, DC, 1985

32 Entrance to Matisse: The Early Years in Nice 1916-1930; National Gallery of Art, Washington, DC

33 Exhibition panel, Kazimir Malevich 1878-1935;

National Gallery of Art, Washington DC, 1990

34 West Building, National Gallery of Art, Washington, DC, 1947

35 Wild Mob Looks for Zoot Suiters, Los Angeles Times, 1943; Jailed Zoot Suiters, Los Angeles Daily News, 1943

36 Joseph Beuys, Bathtub (Show Your Wound), 1960; Wrapped Body, 1971; Private Collection

37 Joseph Beuys, Auschwitz, 1958; Stroher Collection, Hessisches Landesmuseum, Darmstadt

38 Jorg Immendorf, Café Deutschland I, 1978;

Neue Gallery Ludwig Collection, Aachen

39 Jorg Immendorf, Let's go to the 38th Party Conference, 1983; Ulli Knecht Collection, Stuttgart

40 Jochen Gerz, Monument Against Fascism; Hamburg; Collection of the Artist

41 Jochen Gerz, EXIT Dachau Project, 1972-4;

Collection of the Artist

42 Jochen Gerz, Two images of Saarbrücken, 2146 Stones Memorial Against Racism; Collection of the Artist

43 Rembrandt, Female Nude Seated, c.1654-6 (Benesch 1122); The Art Institute of Chicago

44 Rembrandt, Female Nude Seated, c.1660-1

(Benesch 1142); Rijksprentenkabinet, Amsterdam

45 Rembrandt, Female Nude Seated, c.1630-1

(Benesch 21); British Museum, London 
46 Rembrandt, Woman Standing Up (Susanna?) no date

(Benesch 590); Kupferstichkabinett, Berlin

47 Rembrandt, Joseph and Potiphar's Wife, 1634; Teyler

Museum, Haarlem

48 Rembrandt, Judith Beheading Holophernes, c. 1652

(Benesch 897); Meso di Capodimonte, Naples

49 Rembrandt, The Toilet of Bathsheba, 1643 (Bredius 513);

Metropolitan Museum of Art, New York

50 Rembrandt, Danae, 1636 (Bredius 474); Hermitage,

Saint Petersburg

51 Rembrandt, The Blinding of Samson, 1636 (Bredius 501);

Städelsches Kunstinstitut, Frankfurt am Main 167

52 The Room of Herakles 177

53 The Room of Dionysos 178

54 Diagram of overlapping areas in the Imagines 184

55 Diego Velasquez, The Fable of Arachne, 1644-8;

Museo del Prado, Madrid

185

56 Albrecht Dürer, The Martyrdom of the Ten Thousand

Christians, 1598; Kunsthistorisches Museum, Vienna

57 Vittore Carpaccio, Sant' Agostino nello studiolo, 1485?; Scuola di San Giorgio degli Schiavoni, Venice

198

58 Jan van Eyck, The Arnolfini Wedding, 1434;

National Gallery, London

207

208

59 Sandro Botticelli, Adoration of the Magi, 1475; Uffizi

Gallery, Florence

60 Fra Filippo Lippi, Crowning of the Virgin, c. 1445;

Uffizi Gallery, Florence

61 Joseph Thorak, Comraderie

62 Max Ernst, Le Muggissement des féroces soldats, 1919

63 Max Ernst, Trophée hypertrophique, 1919-20 220

64 Max Ernst, Petite machine construite par lui-même, 1919

65 Max Ernst, Ca me fait pisser, $1919 \quad 224$

66 Max Ernst, Adieu mon beau pays de Marie Laurencin, 1919

67 Drawing of a machine devised by the autistic child Joey, from Bruno Bettelheim, The Empty Fortress, 1967

68 Max Ernst, Untitled (Airplane) 1920

69 Hans Bellmer, Machine-Gunneress in a State of Grace, 1937

70 Hans Bellmer, 'Variations sur le montage d'une mineure articulée', Minotaure, 6 (Winter 1934-5) 232

71 Hans Bellmer, Doll (second), $1935 \quad 235$

72 Hans Bellmer, Doll (first), 1934 236

73 Hans Bellmer with La Poupée, 1934; From 'Variations
sur le montage d'une mineure articulée', Minotaure, 6

74 William Hunter, Anatomy of the Human Gravid Uterus, Tab.

IV; The Trustee of the Wellcome Trust, London

75 William Hunter, Anatomy of the Human Gravid Uterus, Tab. VI; The Trustee of the Wellcome Trust, London

76 Gautier d'Agoty, Myologie complette en couleur et grandeur 
naturelle, Plate 4; The Trustee of the Wellcome Trust, London

77 Gautier d'Agoty, Myologie complette en couleur et grandeur naturelle, Plate 7; The Trustee of the Wellcome Trust, London

78 Willliam Hogarth, The Four Stages of Cruelty, Plate 4; by permission of the Trustees of the British Museum

79-83 Wax female figure with moveable parts; The Trustee of the Wellcome Trust, London

84 Anne-Louis Girodet-Trioson, The Sleep of Endymion; Giroudon/ Bridgeman Art Library

85 Adèle Chavassieu, Girodet painting Pygmalion and Galatea, Copy after lost painting by F.L. Dejuinne; Civiche Raccolte d'Arte, Castello Sforzesco, Milan, Deposito Pinacoteca di Brera

86 Diagram of Klein group

87 Diagram of the relation of figure to ground (Klein group)

88 Diagram of castration-fear (Klein group)

89 Jacques Lacon, L-Schema

90 Diagram of the relation of figure to ground (L-Schema) 


\section{Acknowledgements}

The lecture series from which this book proceeds was originally sponsored by the Ray Smith Endowment for the Humanities and the Office of the Vice President for Research and Graduate Affairs at Syracuse University, along with the Kress Foundation. Further financial support came from the School of Visual and Performing Arts and the Departments of English and Fine Arts at the University of Syracuse. Diane Elam also made a major culinary contribution to the success of the series.

The production of this volume was made possible by grants from the Québec Fonds pour la formation des chercheurs et l'aide à la recherche (FCAR) and the Canadian Conseil de la Recherche en Sciences Humaines (CRSH/SSHRC). We are particularly grateful to Gilles Dupuis for his editorial work.

Portions of Mieke Bal's essay have appeared in different form in her book Reading Rembrandt: Beyond the Word $\backslash$ Image Opposition (Cambridge: Cambridge University Press, 1991). A shorter version of John Bender's essay, 'Impersonal Violence: The Penetrating Gaze and the Field of Narration in Caleb Williams' appears in Polhemus and Henkle (eds.), Critical Reconstructions: The Relationship of Fiction and Life, published by Stanford University Press (1994). We are grateful to Cambridge University Press for permission to reproduce Norman Bryson's essay form a volume edited by S. Goldhill and R. Osborne. Michael Ann Holly's essay originally appeared in Critical Inquiry 16 (Winter 1990 ): 371-96. We are grateful to the following institutions for permission to reproduce works from their collections:

The Arts Council of Great Britain, London, for On the Insistence of the Letter by Mary Kelly.

The Arts Institute of Chicago, for Female Nude Seated (Benesch 1122) by Rembrandt van Rijn.

The Brera Gallery, Milan, for Marriage of the Virgin by Raphael.

The British Museum, London for Female Nude Seated (Benesch 21) by Rembrandt van Rijn, The Four Stages of Cruelty by William Hogarth and Young Woman with Binoculars by Edgar Degas.

Civiche Raccolte d'Arte, Castello Sforzesco, Milan, for Girodet painting Pygmalion and Galatea by Adèle Chavassieu. 
The Collection Sirot-Angel for Morisot's Studio (Anonymous).

Galleria Nazionale delle Marche, Palazzo Ducale, Urbino, for The Flagellation of Christ by Piero della Francesca.

Gemäldegalerie, Dresden, for Sleeping Venus by Giorgione da Castelfranco.

Hessisches Landesmuseum, Darmstadt, for Auschwitz by Joseph Beuys.

Kunsthistorisches Museum, Wien, for The Martyrdom of the Ten Thousand, by Albrecht Dürer.

Kupferstichkabinett, Berlin, for Woman Standing Up (Benesch 590) by Rembrandt van Rijn.

Meso di Capodimonte, Napoli, for Judith Beheading Holophernes (Benesch 897) by Rembrandt van Rijn.

The Metropolitan Museum of Art, New York, for The Toilet of Bathsheba by Rembrandt van Rijn.

Musée des Beaux Arts, Nantes, for The Corn Sifters by Gustave Courbet.

Musée d'Orsay, Paris, for Olympia by Édouard Manet.

Musée Fabre, Montpellier, for The Meeting, or Bonjour, Monsieur Courbet by Gustave Courbet.

Museo del Prado, Madrid, for The Fable of Arachne and Las Meninas by Diego Velazquez.

The Museum of Fine Arts, Boston, for Woman in Black by Mary Cassatt.

The Museum of Modern Art, New York, for The False Mirror by René Magritte.

The National Gallery, London, for The Arnolfini Wedding by Jean van Eyck and The Young Schoolmistress by Jean-Baptiste Siméon Chardin.

The National Gallery of Art, Washington DC, for numerous installations and exhibits.

Neue Gallery, Aachen, for Cafe Deutschland I by Jorg Immendorf.

Rijksmuseum Kroeller-Mueller, for Peasant Woman Stooping Seen from Behind and from the Side by Vincent van Gogh.

Rijksprentenkabinet, Amsterdam, for Female Nude Seated (Benesch 1142) by Rembrandt van Rijn.

Scuola di San Giorgio degli Schiavoni, Venezia, for Sant'Agostino nello Studio by Vittore Carpaccio. 
Städelsches Kunstinstitut, Frankfurt am Main, for The Blinding of Samson by Rembrandt van Rijn.

State Hermitage Museum, Saint Petersburg, for Danae (Bredius 474) by Rembrandt van Rijn.

The Tate Gallery, London, for The Meeting, or Have a Nice Day, Mr Hockney by Peter Balke.

Teyler Museum, Haarlem, for Joseph and Potiphar's Wife by Rembrandt van Rijn.

The Uffizi Gallery, Firenze, for Adoration of the Magi by Sandro Botticelli, Crowning of the Virgin by Fra Filippo Lippi and Venus of Urbino by Titian.

Ulli Knecht collection, Stuttgart, for Let's go to the 38th Party Conference by Jorg Immendorf.

The Vatican Museum, Rome, for School of Athens by Raphael.

The Wellcome Trust, London, for Anatomy of the Human Gravid Uterus by William Hunter, Myologie complette en couleur et grandeur naturelle by Gautier d'Agoty and Wax female figure with moveable parts. 


\section{Notes on Contributors}

Mieke Bal is Professor of the Theory of Literature at the University of Amsterdam, and Adjunct Visiting Professor of Visual and Cultural Studies, University of Rochester. Her interests include narrative theory, semiotics, and cultural studies, in particular the relations between discourse and image. Her most recent book is Reading 'Rembrandt': Beyond the Word-Image Opposition (1991). She is currently preparing a book on images in Proust.

John Bender is Professor of English and Comparative Literature at Stanford University. He is the author of Spenser and Literary Pictorialism (1972) and Imagining the Penitentiary: Fiction and the Architecture of the Mind in Eighteenth century England (Chicago, 1987), which was awarded the Gottschalk Prize by the American Society for Eighteenth-Century Studies. He is co-editor of The Ends of Rhetoric: History, Theory, Practice (1990) and of Chronotypes: The Construction of Time (1991).

Norman Bryson teaches art history at Harvard University. He is the author of Word and Image: French Painting of the Ancien Régime (1981) and Looking at the Overlooked: Four Essays on Still Life Painting (1990).

Victor Burgin teaches in the Art History and History of Consciousness programmes at the University of California at Santa Cruz. He is the author of The End of Art Theory: Criticism and Postmodernity (Humanities Press International, 1986), and editor of Thinking Photography (1982) and Formations of Fantasy (1986).

Thomas Crow is Professor of Art History at Sussex University. He is the author of Painters and Public Life in Eighteenth Century Paris (1985).

Peter de Bolla teaches English at King's College, Cambridge. He is the author of The Discourse of the Sublime (1989) and Harold Bloom: Towards Historical Rhetorics (1988).

Hal Foster is Professor of Art History and Comparative Literature at Cornell University. He is the author of Recodings (Bay Press 1985), and Compulsive Beauty (1993). He is the editor of The Anti-Aesthetic: Essays on Postmodern Culture (1983), Discussions in Contemporary Culture (1987), and Vision and Visuality (1988). 
Michael Ann Holly is Professor of Art History and Visual and Cultural Studies at the University of Rochester. She is the author of Panofsky and the Foundations of Art History (1984) and co-editor of Visual Theory (1992) and Visual Culture (1994).

Martin Jay is Professor of History at UC, Berkeley. He is the author of The Dialectical Imagination (1973), Marxism and Totality (1984), Adorno (Harvard 1984), Permanent Exiles (1985), Fin-de-Siècle Socialism (1988), Force Fields (1992) and Downcast Eyes (1993).

Rosalind Krauss is professor of Art History at Columbia University. Cofounder and co-editor of October magazine, her books include Passages in Modern Sculpture (1977), The Originality of the Avant Garde and Other Modernist Myths (1985) and The Optical Unconscious (1993).

Françoise Lucbert works in Comparative Literature and Art History at the Université de Montréal. She is the author of essays on French symbolist art criticism and fin-de-siècle painting.

The late Louis Marin taught at the Ecole des Hautes Etudes en Sciences Sociales and Johns Hopkins University. Among his books are Etudes Sémiologigues: Ecriture, Peinture (1971), Utopics, Spatial Plays (1982), La Critique du Discours (1975), Le Récit est un Piège (1977), Détruire la Peinture (1977), La Voix Excommuniée (1978), The Portrait of the King (1988), Food for Thought (1988), Opacité de la Peinture (1989).

Stephen Melville teaches Art History at Ohio State University, Columbus. He is the author of Philosophy Beside Itself.

Griselda Pollock is Professor of Social and Critical History of Art at The University of Leeds. Her books include Old Mistresses (1981), Framing Feminism (1987), Vision and Difference (1988), and Avant-Garde Gambits: Gender and the Colour of Art History.

Bill Readings was Associate Professor of Comparative Literature at the Université de Montréal until his untimely death in 1994, as this book went to press. He taught in Switzerland and the United States and published on philosophy, literary theory, renaissance studies and art history. He was the author of Introducing Lyotard: Art and Politics and editor, with Bennet Schaber, of Postmodernism Across the Ages.

Irit Rogoff teaches critical theory and visual culture at the University of California - Davis. She is the editor of The Divided Heritage - Problems in German Modernism (1991) and of Museum Culture (1994) and author of the forthcoming Terra Infirma - Geographies and Identities.

Bennet Schaber teaches English at SUNY, Oswego. He is the co-editor of Postmodernism Across the Ages (1993), and author of a forthcoming study of Chaucer.

John Tagg is Professor of Art History at SUNY, Binghamton. He is the author of The Burden of Representation (1988), and editor of The Cultural Politics of 'Postmodernism' (1989). 